\title{
English as a Foreign Language Learning Students' Perceptions of Blended Learning in University Institutions: A Case Study of a University in UAE
}

\author{
Ghadah Al Murshidi* \\ Department of Curriculum and Instruction College of Education, United Arab Emirates University, 15551, United Arab Emirates
}

A R T I C L E I N F O

Article history:

Received: 03 September, 2020

Accepted: 24 September, 2020

Online: 12 October, 2020

\section{Keywords:}

Blended Learning

Online teaching TAM

Q- Methodology

EFL Learners

\begin{abstract}
A B S T R A C T
This study aims to review English as a foreign language learning students' perception of blended learning on various aspects of learning process. The study seeks to answer the question as to whether there is any correlation among students derived independent variable and their perception with respect to the merits and demerits of online blended learning. The Q-methodology was used whereby the questionnaire method was applied and data collection was supported by the Q-Sort data collection model which involves 251 learners who voluntarily presented themselves for $Q$-Method procedural participation and learning at third and fourth grade of English Language Teaching at the university identified within United Arab Emirates. The results showed no statistical difference in means for students' perceptions towards blended learning at significant level 0.05. This thus confirms a higher degree of acceptance for blended learning versus old class mode of learning. The study, therefore, concludes that individual student success was highly increased in blended learning encounters as compared to either complete online or wholly face to face learning encounters. Online blended learning has been seen to optimize maximum benefits of old teaching methods and access to online learning materials.
\end{abstract}

\section{Introduction}

Times are changing in terms of using modern online technology for delivering instruction to expand distance education to attain maximum learning objectives. Immense advancement in internet services and e-learning technology evolved a blended mode of learning (a combination of traditional face-to-face and modern e-learning) [1]. This mode of blended learning proved to be a strong link among students, faculty members and classrooms with different locations to develop and enhance multiple skills especially learning of different languages. Blended learning is a mode of learning in which use of both ordinary teaching, in accord with advanced modern online teaching, and online learning materials are largely applied in its application [2]. As daily norms and routines are followed, electronic online materials are seemingly acquired to complement learning process [3]. This mode of learning also made use of professional establishment and on job training acquisition sessions [2].

Further, [4], expanded the conceptualization of blended learning as a combination of online and physical individual consociate dissemination in which online platform efficiently

\footnotetext{
*Corresponding Author: Ghadah Al murshidi, Email: g_almurshidi@uaeu.ac.ae
}

replace majority of face-to-face learning time other than serving as a supplement. [5] found out that individual student success was highly revealed in blended learning encounters when related to either complete online or wholly face to face learning encounters. Addition of creativity and innovation to make improvement and ability of teaching has yield new openings in learning field [6]. Blended learning is envisioned to optimize maximum benefit of old teaching techniques and internet material access [7] Despite of the immense benefits, yet, this blended learning mode is not widely adopted in higher education and it has been massively passive all about independent on its cadre, as, many approaches have been laid to keep at bay it's application [8], [6].

Previous reports on the topic have revealed laxity in definitions on its mandate, a disgrace that has resulted into limitation of effective research on its application [4], [9], [10], attributed this to few reasons including lack of teacher's familiarity and adaptability as they perceive it less appropriate in terms of stated that, complications which arise in establishing blended learning module units involve limited support, inadequate period, course structuring resource, technological risk on its accessibility, and requirement to acquire most current learning skill. [11] supported researcher efforts to seek 
investigation of approach to blended learning at curriculum level, expound on the concepts of blended learning from the angle of course instructors. On the other hand, the researches focused to examine the efficient component aspects of blended learning in regard to specific learning lesson, the component aspects demanded for institution level blending, for instance, institution support, were neglected [11]- [13]. To make an illustration, even though Poon (2012) summed up that institution support had a mega significance within his research, this material component has for long time been ignored despite the fact that it was meant for institutional embracing of blended learning. Therefore, this research is particularly conducted to reveal the importance of institution support for blended learning. This paper aims to review students' perceptions of blended learning on various aspects of learning process and will address the following questions,

i. Is there any correlation among students derived independent variable (Abilities to learn online, speed of online information capture, Increased capacity of knowledge acquisition) and their perception with respect to the merits and demerits of Blended Learning? (what is the Perceived Ease of Use of the Blended Learning \& Online Learning?)

ii. In which manner does United Arab Emirates university learners perceive effects linked to blended learning regarding how they develop English language learning skills? (How the Perceived usefulness of Blended Learning \& Online Learning lead to positive Behavioral Intention to Use?)

iii. How do learners in United Arab Emirates university perceive blending learning model attesting to its merits and demerits? (How the Perceived Ease of Use of Blended Learning \& Online Learning lead to Positive Behavioral Intention to Use?)

iv. What do the learners suggest for improvement of disseminating and implementing blended course units within English Department? (How to implement Blended Learning \& Online Learning?)

\section{Review of Related Literature}

\subsection{Blended learning}

There are many conceptualizations of blended learning available in literature. [14] defines it as "a combination of online and classroom learning activities using resources in an optimal way in order to improve student learning outcomes and to address important institutional issues". The ideological meaning of blended learning is "enhancing integration of online resources and face to face framework for creating a sleek efficient learning encounter" ([15], p. 98). By application of blended learning, instructors have a capacity to make use of online resource materials within daily classwork lesson dissemination to instigate learners, stimulate individual assertive behavior and mold them to become more efficient in their daily learning routine.

According to [16] blended learning is "a flexibility intensified approach with combination of face to face learning activity encompassing online learning capacity which entrusts learners to exchange collectively acquired and individuals' feedback and response within four specified regions, that's, learner feedback, learner strategy, and alternative synchronous or asynchronous assessment ". Meanwhile [17] refer to blended learning as "a concept that includes framing teaching learning process that incorporates both face to face teaching and teaching supported by ICT, i.e., direct instruction, indirect instruction, collaborative teaching, and individualized computer assisted learning". Finally, [18] define blended learning as "a learning program that improves learning effectiveness through extending the access, optimizing the cost of development and time, as well as optimizing learning outcomes.

\subsection{Principles of Blended learning}

- Blended learning focus on effective achievement of goals.

- Blended learning entails consideration of cumulative learning style frameworks

- Blended learning needs to base on learner's class needs.

- Blended learning availability to learner's knowledge acquisition desire should be present.

It involves 2 modes of interacting: face to face meeting, and website base meeting. Website base interaction may either be synchronously or asynchronously laid [3] The terminology synchronous refers to description of the live on-board training session, online actual time meeting set among course instructors and remotely located learners [19]. Concurrently, asynchronous has a meaning that "instructions stream is just in time, when you require it" [19]. Comparatively face to face learning in conjunction with online learning environment have their merits. However, as [20] points out, "A complexion of learning and teaching techniques all the time will ever be the highest effective criterion for supporting learner's knowledge acquisition as you find out it's the only distinguished mechanism to accept cumulative practices of discussing, interacting, adapting and reflecting on daily learning routines, and essentials of academic knowledge acquisition" [21].

\subsection{Importance of blended Learning in Learning English Language}

In [6], the author conducted a research study to find out the effectiveness of blended learning on "academic achievements, motivation and learner autonomy" while teaching English language via short stories. A quasi-experimental study was conducted among 116 students by utilizing two different teaching pedagogies i.e. for experimental group a blended learning classroom and at the sometime for a control group a conventional learning classroom was spared. There results depicted more positive effects on students' motivation and learner autonomy variables in case of blended learning in comparison to conventional learning. therefore, it can be concluded that blended learning is effective to be applied in English language classes by having proper technical support and required resources.

Similarly, a study was conducted by [5] to find out the English communication skills need of the undergraduate engineering students at workplace by implying Blended Learning and Project-based Learning Approach. They inferred that Blended Learning Module were supported more for English language leaning particularly, for speaking and listening skills. Thus, 
representing the importance of blended learning Module for learning language skills. [18] examined the impact of blended learning on academic achievements of the school students and fond the positive results as compared to the traditional methods of learning. [22] conducted a study to examine the impact of blended learning method on attainment of English language proficiency among the students of $9^{\text {th }}$ grade. They made two groups of female students (50 in each group). One was experimental and other was control. Controlled group was taught English language via traditional method whereas, experimental group was taught by using computerized programs. Results supported the experimental group in terms of more proficiency of learning English language over controlled group representing the importance of blended learning methods in learning English language.

In [23], the auhtor sleeked attention on the outcome of an initially presented model of blended learning and intimately enlisted students' attitude towards English linguistic application while learning medical new words by preparatory medical students at AGU university. He made two assortment of group samples division. One encored a control experimental sample, another one monitored test sample. Outcome implicated none of the samples by statistics significantly illustrated difference amidst the two classified samples regarding individual student achievements in line to attitude towards English. The findings showed also that the control experiment grouped members of the class indicated a reasonable magnitude of contentment pertaining the online learning aspect. [16] conducted a research on the effectivity of making use of blended learning in generating interrogated teacher's training module, and ability to perform. Investigation sample size encompassed 38 English as a foreign language (EFL) voluntary Saudi origin teacher from the school of Arts and Education, Tabuk University. It then followed that the sample to be divided at the two-group differential. From the divisions, group one was instructed to study 4 EFL subjects by means of traditional technique, on the other side group number two was asked to study four correlated subjects making use of blended learning modelled module. Outcomes showed contentiously blended learning module clarified extensively efficient comparison to traditional module while devising voluntary teacher's periodical teaching module. No difference was fond among the two groups depicting the good adaptability level of learners for blended learning method.

In [24], the author investigated elements affecting e-learning student's acceptability for Blackboard in King Khalid University. The study results outlined a demonstration that informant persons made identification of facilitator and inhibitor elements of elearner's experience initially identified within previous study. They as well indicated that learners are prepared for technology implementation acceptance, ready for shifting towards an elearning module. Within similar categorized setting, [5] conducted a study on the school officials and learner's perception of electronic learning within English departmental school and made observation response given extensively were motivating and implied that learning became better within electronic learning setting in comparison to traditional classroom criterion. The lynched investigation attempt to find out intensively more detail perception of EFL students in respect to impact blended learning has on their numeral English language learning skill developments, expected merits of the renewed encounter, redundancy of the designed model of learning culminating expected suggestion to enhance quality of website base learning and teaching at the college and universities.

\subsection{Perceived Usefulness and Intentions to Use Blended and Online Learning Techniques}

According to [25], "perceived usefulness is an individual belief that a technology will make their work better". On the other side, ([26], p. 30) views "perceived usefulness as the degree to which students believe that using technologies will improve their learning performances". Many researchers concede "perceived usefulness" as determinant of the intentions, for using online technologies in learning and teaching activities [27] as, online Learning technologies utilized in teaching facilitate students and teachers with chances to cooperate in creation and sharing of knowledge. "These inform that technologies and tools provide a learning environment in which students can construct their learning experiences and collaborate with others to generate ideas" ([28], p. 18). Therefore, it can be said that students get more benefit out of collaborative learning activities via online system rather than working alone [29]. As stated by [30] that now a day's digital students acquire more knowledge by engaging into relevant and eloquent activities for which online technologies is mandatory.

Additionally, it is imperative to note that online technologies increase blended learning opportunities by creating a learning environment that impart positive effects on students as well as faculty members [5], [31]; [32]. Particularly, language education teachers expressed positive views regarding online learning and specified the pedagogical benefits related to blended learning and online learning technologies [33]. In another study conducted by [34] to examine the adaptability of students towards online learning technologies, they found that according to students few online technologies are very helpful in terms of interaction with fellow beings and teachers and acquisition of more knowledge, and satisfaction with a course etc. [28] expressed that perception of teachers regarding usefulness of online technologies are noteworthy determinants of their intention to use the applications in teaching. Therefore, based on the "Technology Acceptance Model (TAM)", it can be posed that Perceived usefulness of blended and online learning is a significant predictor of intentions to use those technologies in teaching methodologies particularly while teaching and learning English language as foreign language.

H1: The "perceived usefulness" of blended learning \& online learning is positively associated with behavioral intention to use blended \& online learning technologies.

\subsection{Perceived Ease of Use and Intentions to Use Blended and Online Learning Techniques}

"Perceived ease of use refers to the degree to which an innovation (technology) is perceived to be easy to understand and use" ([35], p. 33) "Users of a technology can perceive ease of use of technology when they are exposed to or familiar with it" [5] Similarly, stated by [5] learners start using technologies once they perceive it easy to use. On the other hand, ([36], p. 338) declares that "new ideas and innovations that are easier to understand are 
adopted more rapidly than those that require adopters to develop considerable new skills and understandings". ([37], p. 320) that "perceived ease of use is the degree that using a specific technology will be free of effort". Additionally, [38] research results revealed that perceived ease of use is a strong predictor of intentions of the students to keep on using the online leaning technologies. Likewise, [5] conducted a cross sectional study among 350 respondents and including teachers and students and fond that perceived ease of use is significant predictor of intentions to use the online technologies and was supported by majority of both students as well as teachers. Therefore, based on the "Technology Acceptance Model (TAM)", it can be posed that Perceived Ease of Use of blended and online learning is a significant predictor of intentions to use those technologies in teaching methodologies particularly while teaching and learning English language as foreign language.

H2: The "perceived ease of use" of blended learning \& online learning is positively associated with behavioral intention to use blended \& online learning technologies.

\subsection{Technology Acceptance Model (TAM), Intentions to Use and Actual System Use}

Technology Acceptance Model (TAM) model is applied in this study. The three constructs of the TAM including "perceived usefulness, perceived ease of use, and behavioral intention to use" blended learning and online learning are tested to find out the actual usage of an information system as presented in Figure 1. This implies that teachers and students' readiness to participate in blended and online learning activities are dependent upon their perception about usefulness of these techniques along with ease of sing those. In addition, [27] asserts that there is an affirmative association between intention to use and actual usage of online technology and those intentions are initiated because of Perceived usefulness and Ease of Use of blended and online learning.

Likewise, [39] stated that intentions to use new learning systems results into increased adoption level of the students as well as teachers and ultimately results into more learning capabilities. [40] also concluded that intentions to use technologies leads to actual system usage of those technologies and are aroused on the bases perceived ease of use and perceived usefulness and intentions to use blended and online learning techniques. Therefore, it is posed that in case of high intention to use blended learning and online learning technologies to learn English language, the resultant pledge towards using blended learning and online learning technologies would be high and would be actually predicted by perceived usefulness and perceived ease of use.

H3: There is a positive association between behavioral intention to use blended \& online learning technologies and actual system use.

H4: Behavioral intention blended \& online learning technologies. mediates the relationship between "perceived usefulness" of blended learning \& online learning and actual system use.
H5: Behavioral intention blended \& online learning technologies. mediates the relationship between "perceived ease of use" of the blended learning \& online learning and actual system use.

\subsection{Correlation Hypotheses of the study}

$H_{0}$; There's correlation between students derived independent variable (Abilities to learn online, speed of online information capture, Increased capacity of knowledge acquisition) and their perception with respect to the merits and demerits of Blended Learning.

$$
\mu_{1}=\mu_{2}=\mu_{3=} \mu_{4}
$$

\subsection{Theoretical Framework of the Study}

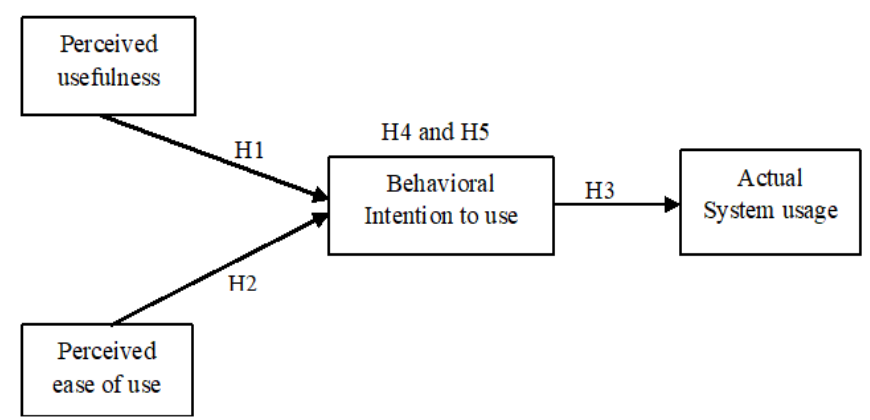

Figure 1: Theractical Framework of the Study

\section{Research Methodology}

\subsection{Research Tools}

In this research, the Q method was employed as mixed method research approach. As a part of it, questionnaire method was applied. The criterion for data collection was supported by the Q-Sort data collection model. A model in which differential sample groups were demarcated in individual allotment data collection units. Q methodology application began in 1930 in psychology field. It was later used in institutional research of social sciences. Its main mandate is to unravel objective perspective, perception, attitude and believes from sampled population of learners in their own discourse, [41]; [42]; [43]; [44]. The Q methodology has been visualized as the most merited data collection technique as it reveals where research group data meets on instantaneous commonly standardized ground on specific topic, and in which direction it is deviated, if that's the scenario [42]. It also helps to develop research outcome amongst commonly identified ideas. Within Q research method, we meet a cemented research model known as Q-Sort model. This model provided guidelines for data collection to perform analysis. Individual factors in its structured framework partition an integration of data acquisition and display aspect. The data partition and clarity in depth display made analysis simple. Data collection was streamlined on the hierarchy of statement listings on the Q- Sort scale. The same is guided by individual learner participants' agreement or disagreement choice selections whose items are listed at the brim of heading titles. The Q methodology is a reality-based research methodology preferably noted choice 
to measure perceptions aligned to a particular phenomenon, presenting it as a generation of both qualitative and quantitative methods of data collection [45]; [42]; [46]. As we progressed, in this research, the main objective inculcated determination of English as foreign language students' perception on blended learning by participants' inducing a total of 47 judgmental statement clauses involving 36 affirmative and eleven negative expression on the Q-Sort model.

\subsection{Data Collection Work Group}

The data collection workable group in the research comprised of 251 English language learners who voluntarily presented themselves for Q-Method procedural participation and learning at third and fourth grade of English Language Teaching at the university identified within United Arab Emirates while in their spring semesters of 2018-2019 academic year. The participant respondents initially have had coursework in "Phonetics and Phonology" and "English Literature Responsive Cultural Pedagogy Work" within blended learning designed model. The provisions to have registered and done a blended course unit there before was used as a determination for main criterion in selecting a cumulative total number of 251 learners. It thus followed, the criteria for sampling method in determination of research sample.

Table 1: Description of research sample Size

\begin{tabular}{|l|l|l|}
\hline Independent Variables & N & $\mathbf{\%}$ \\
\hline $\begin{array}{l}\text { Student Ability to Learn Online. } \\
\text { (Perceived -Usefulness). }\end{array}$ & 9 & $36 \%$ \\
\hline $\begin{array}{l}\text { Speed of online information capture } \\
\text { (Perceived Ease of USE) }\end{array}$ & 5 & $20 \%$ \\
\hline $\begin{array}{l}\text { Students' Perceptions about irrelevancy of } \\
\text { online blended learning } \\
\text { (Behavior Intention) }\end{array}$ & 7 & $28 \%$ \\
\hline $\begin{array}{l}\text { Students' Suggestions on the way forward for } \\
\text { Online Blended Learning Implementation, } \\
\text { Actual System Use) }\end{array}$ & 4 & $16 \%$ \\
\hline TOTAL: & 25 & $100 \%$ \\
\hline
\end{tabular}

Note: * Number of Learners in The Sample: 251

\subsection{Data collection instrument}

Judgmental statement clauses held expression for determination of learners' views at the clinch of 4 headings. A sequential study directive required individual learners to make placement for a total 25 judgmental statement clauses (Nineteen affirmative and six negative) within the Q-Sort model with regard to their individual level of assessment and agreements. This is how the data was collected regardless of the idea that judgmental statement viewpoints within instrument of research was based on the literature.

Q-Sort Model

\begin{tabular}{|l|l|l|l|}
\hline-1 & 0 & 1 & 2 \\
\hline Disagree & Neutral & Agree & Strongly Agree \\
\hline
\end{tabular}

\section{Results and Analysis}

The data of this study was compiled and analyzed by ANOVA (Analysis of Variance), to find out the correlation between students' response statistic with bended learning. The www.astesj.com
Analysis of Variance (ANOVA) was performed by means of a five-step approach. Let us match one by one systematically to find out what will be the outcome.

- Step I: Hypotheses review and Level of significance Setup;

$\mathrm{H} 0: \mu 1=\mu 2=\mu 3=\mu 4$

H1: Standard deviated values away from the normal range

Level of Significance (a) $\alpha=0.05$

- Step II: Test statistic identification.

We decide to use F statistic as it is the standard ANOVA test statistic. Calculated as follows; $\mathrm{F}=\mathrm{MSB} / \mathrm{MSE}$.

- Step III: Decision Rule determined.

The degrees of freedom are required to set up a decision rule. In this case we are enabled to get the critical value of F.

Degrees of freedom calculation.

Degree of Freedom $1(\mathrm{df} 1)=\mathrm{k}-1$

Degree of Freedom $2(\mathrm{df} 2)=\mathrm{N}-\mathrm{k}$.

Now in our case, $\mathrm{dfl}=\mathrm{k}-1=4-1=3$ for all tables, i.e. Table 1 to Table 4.

$\mathrm{df} 2=\mathrm{N}-\mathrm{k}=100-4=96$ for table $1,28-4=24$ for table $2,44-4=40$ for table $3,16-4=12$ for table 4 . From the $\mathrm{F}$ table, the $\mathrm{F}$ value for test statistic in Table 1 is 2.699 , Table 2 is 3.009 , Table 3 is 2.839 , and Table 4 is 3.490 .

Decision rule is that: Reject $\mathrm{H} 0$ in each category if F $>2.699$ for table $1, F>3.009$ for table $2, F>2.839$ for table 3, and when F $>3.490$ for table 4. Rejection is based on the test statistic in each type of the four categories.

\section{- Step IV: Computation of the test statistic.}

In this case we need to complete Analysis of Variance table for ANOVA. We find out sample means, then overall mean after which we will run sum of squares.

$$
\begin{aligned}
\mathrm{SSE} & =\Sigma \Sigma\left(X-\bar{X}_{j}\right)^{2} \\
\mathrm{SSB} & =\Sigma_{n_{j}}\left(\bar{X}_{j}-\bar{X}\right)^{2}
\end{aligned}
$$

(Note: Workings in Excel Sheet)

Table 2: Analysis of Variance (ANOVA)

\begin{tabular}{|l|c|l|l|l|}
\hline $\begin{array}{l}\text { Source of } \\
\text { Variation }\end{array}$ & $\begin{array}{l}\text { Sum of } \\
\text { Squares } \\
\text { (SS) }\end{array}$ & $\begin{array}{l}\text { Degree of } \\
\text { freedom } \\
\text { (df) }\end{array}$ & $\begin{array}{l}\text { Mean } \\
\text { Squares } \\
\text { (MS) }\end{array}$ & $\begin{array}{l}\text { V } \\
\text { Value }\end{array}$ \\
\hline $\begin{array}{l}\text { Between } \\
\text { Treatments 1 }\end{array}$ & - & 3 & 411.828 & 0.113 \\
\hline $\begin{array}{l}\text { Residual } \\
\text { Deviation 1 }\end{array}$ & - & 96 & 3639.455 & \\
\hline $\begin{array}{l}\text { Between } \\
\text { Treatments 2 }\end{array}$ & - & 3 & 739.229 & 3.000 \\
\hline
\end{tabular}


G.A. Murshidi / Advances in Science, Technology and Engineering Systems Journal Vol. 5, No. 5, 893-901 (2020)

\begin{tabular}{|l|c|l|l|l|}
\hline $\begin{array}{l}\text { Residual } \\
\text { Deviation 2 }\end{array}$ & - & 24 & 237.188 & \\
\hline $\begin{array}{l}\text { Between } \\
\text { Treatments 3 }\end{array}$ & - & 3 & 1803.269 & 0.384 \\
\hline $\begin{array}{l}\text { Residual } \\
\text { Deviation 3 }\end{array}$ & - & 40 & 4693.318 & \\
\hline $\begin{array}{l}\text { Between } \\
\text { Treatments 4 }\end{array}$ & - & 3 & 647.064 & 1.389 \\
\hline $\begin{array}{l}\text { Residual } \\
\text { Deviation 4 }\end{array}$ & - & 12 & 465.600 & \\
\hline
\end{tabular}

\section{- Step V: Final Comments}

We accept $\mathrm{H} 0$ hypothesis since $0.113<2.699$ for table 1 , $3.000<3.009$ for table $2,0.384<2.839$ for table 3 , and $1.389<3.490$ for table 4. At significance level of 0.05 , there is no statistical difference in means for students' perceptions towards blended learning. This thus confirms a higher degree of acceptance for blended learning versus old class mode of learning.

\subsection{Correlation Analysis results:}

For analysis purpose Smart PLS 3 was applied. Out of total 251 respondents $55.3 \%$ were male $44.7 \%$ were females. The bivariate correlation analysis in table 1 shows that Perceived Usefulness had a significant positive correlation with Behavioral Intention ( $\mathrm{r}=.38, \mathrm{p}<.01)$, Perceived Ease of Use $(\mathrm{r}=.29, \mathrm{p}<.01)$ and Actual System Usage $(r=.37, \mathrm{p}<.01)$. Similarly, Behavioral Intention had a positive correlation with Perceived Ease of Use $(\mathrm{r}=.66, \mathrm{p}<.01)$ and Actual System Usage $(\mathrm{r}=.48, \mathrm{p}<.01)$. Likewise, Perceived Ease of Use was found to have a positive correlation with Actual System Usage $(\mathrm{r}=.55, \mathrm{p}<.01)$. The $* * *$ on the path coefficient values show excellent correlation between the variables. The survey questions are able to explain $48.1 \%$ of these relationships.

Table 3: Correlation results

\begin{tabular}{|l|l|l|l|l|}
\hline Construct & PU & BI & PEOU & ASU \\
\hline PU & $(0.89)$ & & & \\
\hline BIU & $0.38^{* *}$ & $(0.87)$ & & \\
\hline PEOU & $0.29^{* *}$ & $0.66^{* *}$ & $(0.75)$ & \\
\hline ASU & $0.37^{* *}$ & $0.48^{* *}$ & $0.55^{* *}$ & $(0.79)$ \\
\hline
\end{tabular}

Note: Cronbach's alpha $(\alpha)$ are written in parenthesis $P U=$ Perceived Usefulness; BIU= Behavioral Intention to use; Perceived Ease of Use and ASU=Actual System Usage

To establish internal consistency and to ensure reliability of all constructs Cronbach's alpha and construct reliability was checked. Results of Cronbach's alpha in table 3 reveals that it was higher than standard requirement $(0.7)$ for all the study constructs, i.e. Perceived Usefulness (0.89), Behavioral Intention (0.87), Perceived Ease of Use (0.75), Actual System Usage (0.77). One of the major contributions of this research is the provision of new dimension by converging Online Learning technology, blended learning technology Perceived Usefulness, perceived ease of use, the Learner behavioral intention in relation to its impact on online Learning actual Usage. This study further provides clarification and incremental knowledge in context to other researchers.

\subsection{Direct and mediation hypothesis.}

In table 4 the results depicted that Perceived Usefulness is positively and significantly related to Behavioral Intention of the students $\left(\beta=.633^{* * *}, \mathrm{t}=4.160\right)$ and Perceived Ease of Use is positively and significantly related to Behavioral Intention of the students ( $\left.\beta=.331^{* * *}, \mathrm{t}=3.552\right)$. Therefore, hypothesis 1 , which projected a positive association between the "Perceived usefulness" of Blended Learning \& Online Learning with Behavioral Intention of students to opt for the blended learning and online learning, and hypothesis2, which projected a positive association between "Perceived Ease of Use" of the Blended Learning \& Online Learning with Behavioral Intention of students to opt for the blended learning and online learning is fully supported. Similarly, H3, is fully supported by results given in table 4.

Table 4: Hypotheses Testing Results

\begin{tabular}{|l|l|l|l|l|l|}
\hline \multicolumn{2}{|l|}{ Hypotheses } & $\begin{array}{l}\text { Std. } \\
\text { Beta }\end{array}$ & $\begin{array}{l}\text { t- } \\
\text { Value }\end{array}$ & $\begin{array}{l}\text { p- } \\
\text { Value } \\
\text { s }\end{array}$ & Findings \\
\hline H1 & PU $\rightarrow$ BIU & 0.287 & 2.960 & 0.000 & Supported \\
\hline H2 & PEOU $\rightarrow$ BIU & 0.675 & .710 & 0.010 & Supported \\
\hline H3 & BIU $\rightarrow$ ASU & 0.596 & 5.287 & 0.000 & Supported \\
\hline H4 & $\begin{array}{l}\text { PU } \rightarrow \text { BIU } \rightarrow \\
\text { ASU }\end{array}$ & 0.360 & 3.618 & 0.000 & Supported \\
\hline H5 & $\begin{array}{l}\text { PEU } \rightarrow \text { BIU } \rightarrow \\
\text { ASU }\end{array}$ & 0.400 & 4.519 & 0.000 & Supported \\
\hline
\end{tabular}

Note: $P U=$ Perceived Usefulness; $B I=$ Behavioral Intention to use; Perceived Ease of Use and ASU=Actual System Usage

As depicted in Table 4 the mediation hypotheses $\left(\mathrm{H}_{4}\right.$ and $\left.\mathrm{H}_{5}\right)$ are supported. An indirect and positive effect of "Perceived usefulness" of Blended Learning \& Online Learning was found on Behavioral Intention of students to opt for the blended learning and online learning ( $\left.B=.360^{* * *}, t=3.618, p<0.001\right)$, similarly, an indirect and positive effect of "Perceived Ease of Use" of the Blended Learning \& Online Learning was also found on Behavioral Intention of students to opt for the blended learning and online learning ( $\left.B=.400^{* * *}, t=4.519, p<0.001\right)$. The formal two tailed significance test assuming a normal distribution exhibited that for Perceived usefulness the indirect effect was positive and significant. Further, results show the nonzero value for lower limit and upper limit confidence interval which means that results were significant [47].

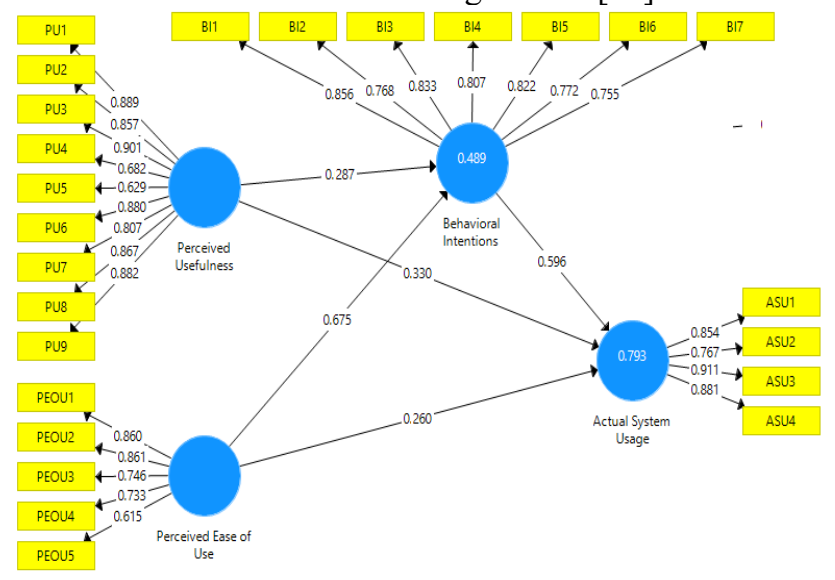

Figure 2: Regression results 


\section{Discussion}

\subsection{Students ability to learn online}

Current study reveals that Perceived Usefulness and Perceived Ease of Use of Blended Learning \& Online Learning directly impact the Behavioral Intention of Students to opt for the blended learning and online learning practices to learn different language (in this study particularly to learn English language ) and those behavioral intentions further increase the adoptability level of the students for Actual System Usage. This study disclosed that the blended online learning format in the modules encouraged students to focus their attention on the topics and issues with less distraction. All evidence-based studies made a conclusion that individual student's success was highly revealed in blended learning encounters when related to either complete online or wholly face to face learning encounters. Outcomes showed contentiously blended learning module clarified extensively efficient comparison to traditional module while devising voluntary teacher's periodical teaching module.

In [48], the author indicated intrinsically students whose preference was for enrollment into online course units displayed higher magnitude within individual abilities to entrust online learning also magnificent confidence in relation to online knowledge acquisition compared to the other students using the old learning technique. The study also noted that integration of blended online discussions format in their courses allowed them to construct their own thinking rather than just passively accepting what others thought. This study also noted that blended online learning format encouraged students to be creative i.e. having the ability to think critically of an issue in novel and unusual ways and come up with unique conclusions resulting into enhanced ability to learn English. [49] noted that the magnitude of students' contentment, expectation, opinion, or viewpoints on various unit programs performed a significant role in evaluation of efficiency in learning process and that is a pre-requite for learning a foreign language i.e. English Language.

\subsection{Speed of online information}

This study also reveals that there was no significance difference $(P<0.05)$ in the speed of online information accessed among the students. The integration of online blended discussion format in their course encouraged in-depth discussion of the ideas and concepts taught in the English language course among students. Also, the online learning discussion format prevented students from wasting time in non-course activities like disturbance, commuting, and unnecessary social interactions. These findings are in line with the study of [50] that mapped Egypt university EFL student's knowledge acquisition skills and contentment linked to website base material components that had individual's contentment with internet illuminated material set. The blended online discussion format encouraged students to spend more time focused on topics and issues at hand very easily. Incorporating learners in an online blended learning session has a huge promising effect on wider knowledge acquisition and at the same time providing response to peer related question sets, live share of borne ideology including acquisition of timely outcomes from their course instructors.

\subsection{Students' Perceptions about irrelevancy of Online blended} learning capacity of knowledge acquisition

The study noted that Online learning discussion format allowed more students to feel more comfortable asking awkward questions but others thought that lack of social interactions in the online discussions affected their understanding and learning as well as difficulty in participating in the Online discussions since due to the lack of face-to-face interaction aspect during the discussions. However, some students noted that they spent too much time learning to use technology instead of focusing on the discussion part of the module. Others felt that online discussion format in their course made them feel isolated from the instructor. This study found that there is no significant difference in means for students' perceptions towards blended learning.

This concurs with [51] study which confirms a higher degree of acceptance for blended learning versus old class mode of learning and that student's attitude towards blended learning were motivating regarding processes, convenience in usage and satisfaction, putting a contextual comprehension format on course materials. This study has indicated greater motivating perception responses aligned to beneficial aspects of blended online learning, such as the accessibility, convenience, and resource endowment factor. A study by [5] on perception of blended learning within Saudi colleges and university institutions concluded that the merit of this blended online learning model of knowledge acquisition was applauded at the University and College Education Ministry in Saudi since it was found to provide a remedy to the shortcomings emanating within college students learning in response to a highly replicating college learner demography.

In [52] the author noted that e-Learning within Saudi universities and colleges had capabilities and challenges that was envisioned within the e-learning acceptability that was determined by numerous influential factors. One of these factors is the learner's perception towards blended electronic learning. This shows how much the student like online learning and how frequently does the individual student make use of it. This study also noted that student's ability to decide on to blended online learning is significantly influenced by and subject to who surrounds or who is nearby. These are the people they highly value like their tutors, lecturers, or even parents. Furthermore, they perceived notion of whether blended online learning was accessible or not, plays an intensive role on deciding on whether to accept its usability or not. These findings are imperative in the seamless technology use acceptability.

\subsection{Students' Suggestions on the way forward for Online Blended Learning}

This study has revealed that members of the class indicated a reasonable magnitude of contentment pertaining the online learning aspect. The students' suggestions on the way forward for online blended learning was not statistically difference $(P<0.05)$ indicating that combination of traditional learning process techniques with technological online learning techniques have a positive output to the success of a learner to read and comprehend different languages. These findings are in concurrence with report by [53] who envisaged in a case study 
within the Iranian higher education setting that combining traditional learning process instructions with technological reference online material may have an intense output to the success of a learner to read and comprehend. This study also found out that students would recommend the online blended learning courses to their fellow students because of motivation and enjoyable online discussion in the course and appreciated the online discussion of the course with deadline attached to it.

\section{Conclusion}

As current study examined the factors influencing blended learning adoptions, results revealed that perceived usefulness proved to be the most powerful factor of blended learning along with perceived ease of use that creates intentions to use blended and online learning among teachers and students for learning English Language. The logic can be that blended learning is adopted by academicians in lieu of the fact that they perceive the online technology as useful tool of learning and teaching, therefore, they are interested to focus on the usefulness of the technology as well as its perceived ease of use in adopting it. This study has found out that individual student success was highly revealed in blended learning encounters when related to either complete online or wholly face to face learning encounters. Blended learning has been seen to optimize maximum benefits of old teaching methods and access to online learning materials. This study, therefore, confirms a higher degree of acceptance among students for blended learning versus old class mode of learning technique. We also conclude that there is a significant correlation among students derived independent variable i.e. abilities to learn online, speed of online information capture, Increased capacity of knowledge acquisition, and their perception with respect to the merits and demerits of blended learning.

\section{Conflict of Interest}

The authors declare no conflict of interest.

\section{References}

[1] X. Li, Y. Yang, S.K.W. Chu, Z. Zainuddin, Y. Zhang, "Applying blended synchronous teaching and learning for flexible learning in higher education: an action research study at a university in Hong Kong," Asia Pacific Journal of Education, 1-17, 2020, doi:10.1080/02188791.2020.1766417.

[2] J.C. Evans, H. Yip, K. Chan, C. Armatas, A. Tse, "Blended learning in higher education: professional development in a Hong Kong university," Higher Education Research and Development, 39(4), 643-656, 2020, doi:10.1080/07294360.2019.1685943.

[3] P. Bazelais, T. Doleck, "Blended learning and traditional learning: A comparative study of college mechanics courses," Education and Information Technologies, 23(6), 2889-2900, 2018, doi:10.1007/s10639018-9748-9.

[4] C.R. Graham, W. Woodfield, J.B. Harrison, "A framework for institutional adoption and implementation of blended learning in higher education," Internet and Higher Education, 18, 4-14, 2013, doi:10.1016/j.iheduc.2012.09.003.

[5] K.-T. Wong, G.-J. Hwang, P.S. Choo Goh, S.K. Mohd Arrif, N. Wang, J. Chen, M. Tai, J. Zhang, R. Wanchid, N. Van Long, J. Van Exel, G. De Graaf, P.A. Towndrow, C. Cheers, Z. Tatli, H.İ. Akbulut, D. Altinisik, K. Spring, C.R. Graham, D.R. Serrano López, D. Ayuela, M. Auxiliadora, E. González Burgos, A. Serrano Gil, K. Lalatsa, R.D. Rogers, K.R. Seddon, W.S. Robinson, N.A. Rahman, et al., "Cognitive presence in online learning," Education and Information Technologies, 13(1), 643-656, 2020.

[6] K.T. Wong, G.J. Hwang, P.S.C. Goh, S.K. Mohd Arrif, "Effects of blended learning pedagogical practices on students' motivation and autonomy for the teaching of short stories in upper secondary English," Interactive Learning
Environments, 28(4), 512-525, 2020, doi:10.1080/10494820.2018.1542318.

[7] N.A. Rahman, N. Arifin, M. Manaf, M. Ahmad, N.A. Mohd Zin, M. Jamaludin, "Students' Perception in Blended Learning among Science and Technology Cluster Students," in Journal of Physics: Conference Series, IOP Publishing: 12012, 2020, doi:10.1088/1742-6596/1496/1/012012.

[8] L. Martín-Martínez, V. Sainz, F. Rodríguez-Legendre, "Evaluation of a blended learning model for pre-service teachers," Knowledge Management and E-Learning, 12(2), 147-164, 2020, doi:10.34105/j.kmel.2020.12.008.

[9] D.J. Lemay, M.M. Morin, P. Bazelais, T. Doleck, "Modeling Students' Perceptions of Simulation-Based Learning Using the Technology Acceptance Model," Clinical Simulation in Nursing, 20, 28-37, 2018, doi:10.1016/j.ecns.2018.04.004.

[10] C. Porumb, S. Porumb, B. Orza, A. Vlaicu, "Blended Learning Concept and its Applications to Engineering Education," in Advanced Engineering Forum, Trans Tech Publ: 55-64, 2013, doi:10.4028/www.scientific.net/aef.8-9.55.

[11] N. Wang, J. Chen, M. Tai, J. Zhang, "Blended learning for Chinese university EFL learners: learning environment and learner perceptions," Computer Assisted Language Learning, 1-27, 2019, doi:10.1080/09588221.2019.1607881.

[12] T. Doleck, S.P. Lajoie, P. Bazelais, "Social networking and academic performance: A net benefits perspective," Education and Information Technologies, 24(5), 3053-3073, 2019, doi:10.1007/s10639-019-09913-3.

[13] J. Jia, D. Xiang, Z. Ding, Y. Chen, Y. Wang, Y. Bai, B. Yang, "An effective approach using blended learning to assist the average students to catch up with the talented ones," Knowledge Management and E-Learning, 5(1), 2541, 2013, doi:10.34105/j.kmel.2013.05.003.

[14] H. Kanuka, D.R. Garrison, "Cognitive presence in online learning," Journal of Computing in Higher Education, 15(2), 21-39, 2004 doi:10.1007/BF02940928.

[15] A. Brew, "Disciplinary and interdisciplinary affiliations of experienced researchers," Higher Education, 56(4), 423-438, 2008, doi:10.1007/s10734007-9102-4.

[16] M.F. Badawi, "Using Blended Learning for Enhancing EFL Prospective Teachers' Pedagogical Knowledge and Performance.," Online Submission, 2009

[17] D. Lalima, K.L. Dangwal, "Blended learning: An innovative approach," Universal Journal of Educational Research, 5(1), 129-136, 2017.

[18] V.K. Ceylan, A. Elitok Kesici, "Effect of blended learning to academic achievement," Journal of Human Sciences, 14(1), 308, 2017, doi:10.14687/jhs.v14i1.4141

[19] L. Bielawski, D.S. Metcalf, Blended elearning: Integrating knowledge, performance, support, and online learning, Human Resource Development, 2003

[20] D. Laurillard, "The educational challaenges for teachers and learners," in Virtual University Conference, 1996

[21] P.A. Towndrow, C. Cheers, "Learning to communicate effectively in English through blended e-learning," 2003

[22] D.A. Hijazi, A.S. AlNatour, "The effect of using blended learning method on students' achievement in english and their motivation towards learning it: Blended learning, achievement, and motivation," International Journal of Virtual and Personal Learning Environments, 10(2), 83-96, 2020, doi:10.4018/IJVPLE.2020070106.

[23] A.A. Alshwiah, "The Effects of a Blended Learning Strategy in Teaching Vocabulary on Premedical Students' Achievement, Satisfaction and Attitude toward English Language.," Online Submission, 2009.

[24] A. AHmad, M. Al-Faqeeh, "Strategic leadership of the heads of academic departments: A field study at the University of Najran," Journal of Education, 1(146), 571-615, 2011.

[25] R. Echeng, A. Usoro, I. Ewuzie, "Factors to Consider when Enhancing the Use of Web 2.0 Technologies in Higher Education: Students' and Lectures' Views for Quality Use," International Journal for Digital Society, 7(1), 2016, doi:10.20533/ijds.2040.2570.2016.0138.

[26] K.J. Spring, C.R. Graham, "Thematic patterns in international blended learning literature, research, practices, and terminology," Online Learning Journal, 21(4), 337-361, 2017, doi:10.24059/olj.v21i4.998.

[27] B.J.J. Muries, "Explaining Electronic Learning Management Systems (ELMS) Continued Usage Intentions among Facilitators in Higher Education Institutions (HEIs) in Tanzania.," International Journal of Education and Development Using Information and Communication Technology, 13(1), 123-141, 2017.

[28] S.S. Khanal, P.W.C. Prasad, A. Alsadoon, A. Maag, "A systematic review: machine learning based recommendation systems for e-learning," Education and Information Technologies, 25(4), 2635-2664, 2020, doi:10.1007/s10639-019-10063-9. 
[29] F. Ndumbaro, "Exploring students' conceptions of collaborative information use and information use outcomes in credit-based group learning assignments," University of Dar Es Salaam Library Journal, 13(2), 65-79, 2018.

[30] A. Jimoyiannis, P. Tsiotakis, D. Roussinos, "Social network analysis of students' participation and presence in a community of educational blogging," Interactive Technology and Smart Education, 10(1), 15-30, 2013, doi:10.1108/17415651311326428.

[31] N. Emelyanova, E. Voronina, "Introducing blended learning in the English language classroom: Students' attitudes and perceptions before and after the course," Knowledge Management and E-Learning, 9(1), 33-49, 2017, doi:10.34105/j.kmel.2017.09.003.

[32] S. Majid, P. Yang, H. Lei, G. Haoran, "Knowledge sharing by students: Preference for online discussion board vs face-to-face class participation," in Lecture Notes in Computer Science (including subseries Lecture Notes in Artificial Intelligence and Lecture Notes in Bioinformatics), Springer: 149159, 2014, doi:10.1007/978-3-319-12823-8_16.

[33] W.W.K. Ma, A.H.K. Yuen, "Understanding online knowledge sharing: An interpersonal relationship perspective," Computers and Education, 56(1), 210-219, 2011, doi:10.1016/j.compedu.2010.08.004.

[34] R. Hartshorne, H. Ajjan, "Examining student decisions to adopt Web 2.0 technologies: Theory and empirical tests," Journal of Computing in Higher Education, 21(3), 183-198, 2009, doi:10.1007/s12528-009-9023-6.

[35] R.D. Rogers, K.R. Seddon, "Ionic liquids--solvents of the future?," Science, 302(5646), 792-793, 2003.

[36] W.S. Robinson, "Ecological correlations and the behavior of individuals," International Journal of Epidemiology, 40(4), 1134, 2011, doi:10.1093/ije/dyr082.

[37] F.D. Davis, "Perceived usefulness, perceived ease of use, and user acceptance of information technology," MIS Quarterly: Management Information Systems, 13(3), 319-339, 1989, doi:10.2307/249008.

[38] L.W. Leong, O. Ibrahim, M. Dalvi-Esfahani, H. Shahbazi, M. Nilashi, "The moderating effect of experience on the intention to adopt mobile social network sites for pedagogical purposes: An extension of the technology acceptance model," Education and Information Technologies, 23(6), 24772498, 2018, doi:10.1007/s10639-018-9726-2.

[39] S.A. Pradia, "Understanding College Students' Readiness to Use Web 2.0 Technologies in Online Education," ProQuest Dissertations and Theses, 137, 2016.

[40] K. Kazoka, J.E. and Mwantimwa, "Perceived Usefulness and Ease of Use of Web 2.0 tools in University Teaching and Learning in Tanzania," University of Dar Es Salaam Library Journal, 14(2), 19-37, 2019.

[41] F. Demir, M. Kul, "Modern bir araştırma yöntemi olarak; Q metodu," Ankara: Adalet Yayınları, 2011.

[42] N. Herrington, J. Coogan, "Q methodology: an overview," Research in Teacher Education, 1(2), 24-28, 2011.

[43] M. Mansoor, T.M. Awan, B. Alobidyeen, "Structure and Measurement of Customer Experience Management," International Journal of Business and Administrative Studies, 6(4), 171-182, 2020, doi:10.20469/ijbas.6.10001-4.

[44] B.B. Mckeown, D.B. Thomas, In : Q Methodology, Sage publications, 2016.

[45] S.R. Brown, "Q Methodology and Qualitative Research," Qualitative Health Research, 6(4), 561-567, 1996, doi:10.1177/104973239600600408.

[46] V.E. Job, G. De Graaf, "Q Methodology : A Sneak Preview Q methodology : A sneak preview," (March), 2016.

[47] M. Mansoor, T. Fatima, S. Ahmed, "Signaling Effect of Brand Credibility Between Fairness (Price, Product) and Attitude of Women Buyers," Abasyn Journal of Social Sciences, 13(1), 263-276, 2020.

[48] A.R. Artino, "Online or face-to-face learning? Exploring the personal factors that predict students' choice of instructional format," Internet and Higher Education, 13(4), 272-276, 2010, doi:10.1016/j.iheduc.2010.07.005.

[49] B. Akkoyunlu, M.Y. Soylu, "A study of student's perceptions in a blended learning environment based on different learning styles," Educational Technology and Society, 11(1), 183-193, 2008.

[50] A.M. Aliweh, "The effect of electronic portfolios on promoting Egyptian EFL college students' writing competence and autonomy," Asian EFL Journal, 13(2), 90-132, 2011.

[51] D. Adas, W.A. Shmais, "Students' Perceptions Towards Blended Learning Environment Using the OCC," An - Najah Univ. J. Res. (Humanities)., 25(6), 1681-1710, 2011.

[52] K.A.S. Al-Harbi, "e-Learning in the Saudi tertiary education: Potential and challenges," Applied Computing and Informatics, 9(1), 31-46, 2011, doi:10.1016/j.aci.2010.03.002.

[53] F. Behjat, M. Yamini, M.S. Bagheri, "Blended Learning: A Ubiquitous Learning Environment for Reading Comprehension," International Journal of English Linguistics, 2(1), 97, 2012, doi:10.5539/ijel.v2n1p97. 